\title{
Group I Metabotropic Glutamate Receptors mGluR1 $\alpha$ and mGluR5a: Localization in Both Synaptic Layers of the Rat Retina
}

\author{
Peter Koulen, ${ }^{1}$ Rainer Kuhn, ${ }^{2}$ Heinz Wässle, ${ }^{1}$ and Johann Helmut Brandstätter ${ }^{1}$ \\ ${ }^{1}$ Max-Planck-Institut für Hirnforschung, Abteilung für Neuroanatomie, D-60528 Frankfurt am Main, Germany, and ${ }^{2}$ CNS \\ Research, CIBA, CH-4002 Basel, Switzerland
}

\begin{abstract}
We examined the distribution of the group I metabotropic glutamate receptors, mGluR $1 \alpha$ and mGluR5a, in the adult rat retina and during postnatal development using receptorspecific antisera. In contrast to the restricted localization of group II and group III mGluRs to either the outer plexiform layer (OPL) or the inner plexiform layer (IPL), group I mGluRs are present in both synaptic layers in the rat retina. Double-labeling experiments and electron microscopy showed that in the OPL the two receptors are localized on the dendritic tips of bipolar cells postsynaptic to photoreceptor terminals. In the IPL the
\end{abstract}

two mGluRs are localized on amacrine cell processes postsynaptic to bipolar cell terminals. These results suggest that group I mGluRs are involved in synaptic processing in both plexiform layers and in both the scotopic and photopic pathways in the rat retina. We propose that mGluR $1 \alpha$ and mGluR5a play an important modulatory role in the responses of retinal neurons to inhibitory and excitatory neurotransmitters.

Key words: mGluR1 $\alpha$; mGluR5a; bipolar cells; amacrine cells; outer plexiform layer; inner plexiform layer; rat retina; retinal development; immunocytochemistry
In the mammalian retina glutamate is the major excitatory neurotransmitter used in visual information processing. The flow of visual information in the vertical direction from the photoreceptors to bipolar cells and horizontal cells in the OPL and from bipolar cells to amacrine cells and ganglion cells in the IPL is mediated via glutamate (for review, see Massey, 1990). This flow of information is modulated by the laterally connecting inhibitory interneurons, horizontal cells and amacrine cells, that preferentially use GABA or glycine as their neurotransmitters (for review, see Brecha, 1983; Yazulla, 1986; Massey and Redburn, 1987; Marc, 1989).

Glutamate acts on two different classes of receptors, ionotropic and metabotropic glutamate receptors. Ionotropic glutamate receptors mediate fast excitatory synaptic transmission (for review, see Monaghan et al., 1989; Seeburg, 1993; Hollmann and Heinemann, 1994), whereas metabotropic glutamate receptors (mGluRs) are G-protein-coupled proteins that bind the ligand, influence a variety of intracellular second messenger systems, and modulate neuronal activity (for review, see Pin and Duvoisin, 1995). Glutamate can act in an excitatory or inhibitory manner via the action of mGluRs.

So far eight different members of the mGluR family have been cloned. Based on sequence homologies, pharmacological properties, and second messenger systems, mGluRs can be subdivided into three groups (for review, see Hollmann and Heinemann, 1994; Nakanishi, 1994; Pin and Duvoisin, 1995). MGluR2, 3 (group II) and mGluR4, $6,7,8$ (group III) are functionally coupled to adenylyl cyclase and inhibit the formation of cAMP in artificial expression systems (Tanabe et al., 1992, 1993; Nakajima et al., 1993; Nakanishi, 1994;

Received Oct. 10, 1996; revised Jan. 6, 1997; accepted Jan. 9, 1997.

This study was supported by Grant SFB 269/B4 from the Deutsche Forschungsgemeinschaft. We thank A. Leihkauf, G.-S. Nam, and W. Hofer for excellent technical assistance and Dr. E. Fletcher for critically reading and improving this manuscript.

Correspondence should be addressed to Dr. Johann H. Brandstätter, Max-PlanckInstitut für Hirnforschung, Abteilung für Neuroanatomie, Deutschordenstrasse 46, D-60528 Frankfurt am Main, Germany.

Copyright (C) 1997 Society for Neuroscience $0270-6474 / 97 / 172200-12 \$ 05.00 / 0$
Okamoto et al., 1994; Saugstad et al., 1994; Duvoisin et al., 1995). MGluR1 and mGluR5 (group I), are activated most strongly by quisqualate. They are functionally coupled to stimulation of phospholipase $\mathrm{C}$, increased synthesis of inositol 1,4,5-trisphosphate $\left(\mathrm{IP}_{3}\right)$, and $\mathrm{Ca}^{2+}$ release from internal stores (Masu et al., 1991; Abe et al., 1992; Aramori and Nakanishi, 1992).

The presence of mGluR1 and mGluR5 in the rat retina was shown with in situ hybridization at the mRNA level (Hartveit et al., 1995) and for mGluR $1 \alpha$ with immunocytochemistry at the protein level (Peng et al., 1995). Several components of a possible pathway involving glutamate and $\mathrm{IP}_{3}$ signaling, e.g., phosphatidylinositol diphosphate $\left(\mathrm{PIP}_{2}\right), \mathrm{IP}_{3}$, and $\mathrm{IP}_{3}$ receptors, also were shown to be present in the rat retina (Anderson et al., 1985; Das et al., 1986; Milani et al., 1990; Peng et al., 1991). However, knowledge on the exact distribution of group I mGluRs in the retina with respect to cellular and subcellular localization and their possible function in retinal synaptic circuitry is still lacking.

We have examined light and electron microscopically the cellular and subcellular distribution of mGluR $1 \alpha$ and mGluR5a in the rat retina using receptor-specific antisera. We show that group I mGluRs are used in synaptic processing in both synaptic layers in the rat retina and suggest that these receptors play an important role in the modulation of the responses of retinal neurons to inhibitory and excitatory neurotransmitters.

\section{MATERIALS AND METHODS}

Antisera against $m G l u R 1 \alpha$ and $m G l u R 5 a$. The affinity-purified polyclonal antiserum against mGluR1 $\alpha$ was obtained from Chemicon (AB1551, Chemicon, Temecula, CA) and was generated in rabbit against a C-terminal peptide of rat mGluR1 $\alpha$ (PNVTYASVILRDYKQSSSTL) conjugated to keyhole limpet hemocyanin. The affinity-purified polyclonal antiserum against mGluR5a also was raised in rabbit against a peptide corresponding to the C-terminal amino acid sequence of rat mGluR5a (PSSPKYDTLIIRDYTQSSSSL) conjugated to ovalbumin (Vidnyánszky et al., 1994).

Animals and tissue preparation. Retinas of adult albino rats, $6-8$ weeks of age, and of different postnatal stages, 1-30 d old, were investigated. For the developmental studies, only retinas from the same litter mates 

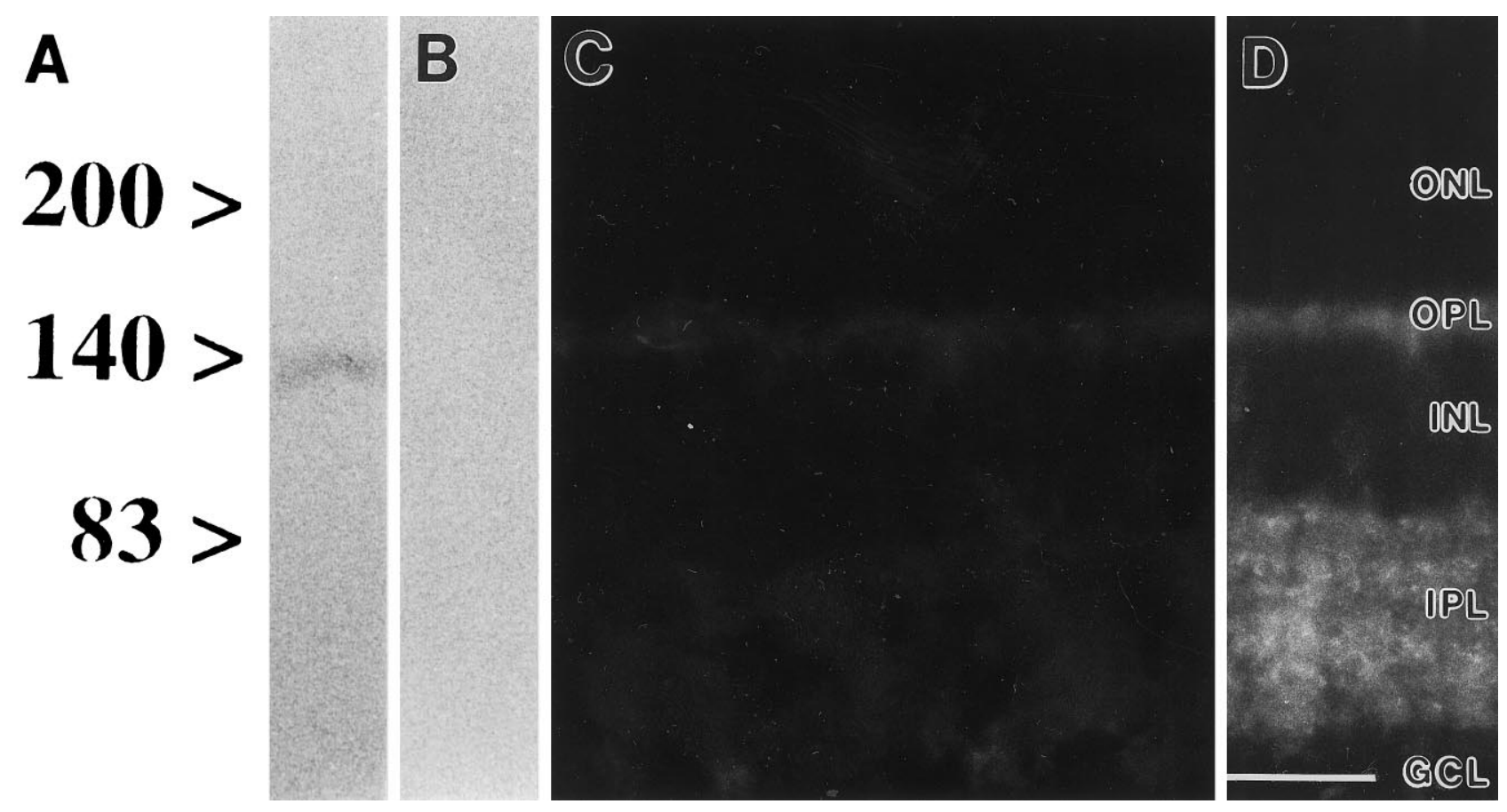

Figure 1. Specificity of the antiserum against mGluR1 $\alpha$. Membrane proteins of retina $(80 \mu \mathrm{g} /$ lane $)$ were separated on a $7.5 \%$ SDS-PAGE gel and transferred onto nylon membrane. Numbers and arrowheads in $A$ indicate the position and weight (kDa) of marker bands. $A$, The antiserum labeled a protein band at $\sim 140 \mathrm{kDa}$. $B$, Labeling was prevented by coincubation of the antiserum with the antigenic peptide. $C$, $D$, On retina sections preadsorption of the antiserum with its antigenic peptide resulted in the loss of specific immunoreactivity $(C)$ compared with the specific mGluR1 $\alpha$ immunostaining $(D)$. $O N L$, Outer nuclear layer; $O P L$, outer plexiform layer; $I N L$, inner nuclear layer; $I P L$, inner plexiform layer; $G C L$, ganglion cell layer. Scale bar, $25 \mu \mathrm{m}$ (shown in $D$ for $C, D$ ).

and only retinal pieces with the same eccentricity were compared. The rats were anesthetized deeply with halothane and decapitated. A detailed description of the preparation of the retinal tissue for light and electron microscopic immunocytochemistry is given in Brandstätter et al. (1996).

Light microscopic immunocytochemistry. In addition to the antisera against mGluR1 $\alpha(0.2 \mu \mathrm{g} / \mathrm{ml})$ and against mGluR5a $(1 \mu \mathrm{g} / \mathrm{ml})$, we used the monoclonal antibody MC-3A against PKC $\alpha$ (1:100; Seikagaku, Tokyo, Japan). Immunocytochemical labeling was performed by the indirect fluorescence method. To characterize the cellular distribution of mGluR5a in more detail, we combined the mAb MC-3A against PKC $\alpha$, known to stain rod bipolar cells (Greferath et al., 1990), in doublelabeling experiments with the specific anti-peptide antiserum against mGluR5a. The binding sites of the primary antibodies were revealed by secondary antibodies: goat anti-mouse or goat anti-rabbit IgG coupled either to carboxymethylindocyanine (Cy3, red fluorescence; Dianova, Hamburg, Germany) diluted 1:1000 or fluorescein isothiocyanate (FITC, green fluorescence; Sigma-Aldrich, Deisenhofen, Germany) diluted 1:100 or to Texas Red (red fluorescence; Amersham, Braunschweig, Germany) diluted 1:100. In the double-labeling experiments, sections were incubated in a mixture of the primary antibodies, followed by a mixture of the secondary antibodies.

Preembedding immunoelectron microscopy. After blocking, vibratome sections $(50 \mu \mathrm{m}$ thick) were incubated in primary antisera against mGluR5a and mGluR $1 \alpha$ for $4 \mathrm{~d}$ at $4^{\circ} \mathrm{C}$. The primary antisera were used at the same concentration and diluted in the same medium, but without Triton X-100, as used for light microscopy.

Detection of the immunostaining and microscopic analysis were performed as previously described (Brandstätter et al., 1996).

Characterization of the antisera against $m G l u R 1 \alpha$ and mGluR5a. The antiserum against mGluR5a has been fully characterized and used previously for light and electron microscopic distribution studies (Vidnyánszky et al., 1994). The specificity of the antiserum against mGluR1 $\alpha$ was assessed by immunoblotting of rat retina membrane proteins (Fig. $1 A, B$ ). Albino rats were deeply anesthetized and decapitated. The retinas were dissected and homogenized in lysis buffer containing 4 mM HEPES, 220 mM D(+)-mannose, $70 \mathrm{~mm}$ sucrose, $1 \mathrm{mg} / \mathrm{ml}$ benzamidine hydrochloride, $0.5 \mathrm{mg} / \mathrm{ml}$ aprotinin (Merck, Darmstadt, Germany), and $0.25 \mathrm{mg} / \mathrm{ml}$ benzethonium chloride (Sigma-Aldrich) at $\mathrm{pH} 7.5$, centrifuged for $3 \mathrm{~min}$ at $1000 \times g$ and $4^{\circ} \mathrm{C}$. Subsequently, the supernatant was centrifuged for $15 \mathrm{~min}$ at $15,000 \times \mathrm{g}$. The pellet was resuspended in lysis buffer to obtain a crude retinal membrane protein fraction. After denaturation with SDS and 2-mercaptoethanol, crude retinal membrane proteins $(80 \mu \mathrm{g} / \mathrm{lane})$ and biotinylated SDS molecular weight markers were electrophoresed on $7.5 \%$ SDS-polyacrylamide gels. Proteins were transferred onto cationized nylon membranes by standard Western blotting technique. After incubation with blocking buffer [5\% (v/v) normal goat serum (NGS) and $0.05 \%$ $(\mathrm{w} / \mathrm{v})$ Tween 20 in PBS (0.01 M), $\mathrm{pH} 7.4$ ] for $1 \mathrm{hr}$ at room temperature, blots were incubated with primary $(0.1 \mu \mathrm{g} / \mathrm{ml})$ and secondary antibodies for $1 \mathrm{hr}$ each in blocking buffer. Binding of the antiserum against mGluR $1 \alpha$ to polypeptides was detected by goat anti-rabbit IgG antibodies coupled to alkaline phosphatase (diluted 1:100; Dianova) with 5-bromo-4-chloro-3-indolyl phosphate and nitroblue tetrazolium (Boehringer Mannheim Biochemica, Mannheim, Germany) as substrates.

The antiserum against mGluR $1 \alpha$ detected a single protein band with a molecular weight of $\sim 140 \mathrm{kDa}$ in membrane preparations of rat retina (Fig. 1A). This is in agreement with the published molecular weight of mGluR $1 \alpha$ deduced from its cDNA sequence (Masu et al., 1991). Preincubation of the antiserum against mGluR $1 \alpha$ with a 10 -fold excess $(w / w)$ of the antigenic peptide led to no labeling in the subsequent immunoblot analysis (Fig. $1 B$ ).

For staining of retina sections, controls were made by preincubating the antisera against mGluR $1 \alpha$ and mGluR5a with a 10 -fold excess of their respective antigenic peptides for $1 \mathrm{hr}$ at room temperature, resulting in a complete loss of specific staining (Figs. $1 C, 3 B$ ). In double-labeling experiments, controls were prepared by omitting one of the two primary antibodies during the incubation, and in this case, only the immunoreactivity for the remaining primary antibody was detected.

In addition, we tested the specificity of the antiserum against mGluR5a and mGluR $1 \alpha$ by staining sections of adult rat brain. Unfixed rat brains were sectioned on a cryostat at $18 \mu \mathrm{m}$ thickness, collected on gelatincoated slides, postfixed for $5 \mathrm{~min}$ in $4 \%(\mathrm{w} / \mathrm{v})$ paraformaldehyde in phosphate buffer, and immunostained as described for the retina sections. Immunolabeling was detected with a biotinylated goat anti-rabbit $\mathrm{IgG}$ (1:100; Sigma-Aldrich) and extravidin-coupled peroxidase (1:100; SigmaAldrich). After preincubation with $0.05 \%$ (w/v) 3, 3'-diaminobenzidine (DAB; Sigma-Aldrich), the sections were reacted by adding $0.01 \%(\mathrm{v} / \mathrm{v})$ 

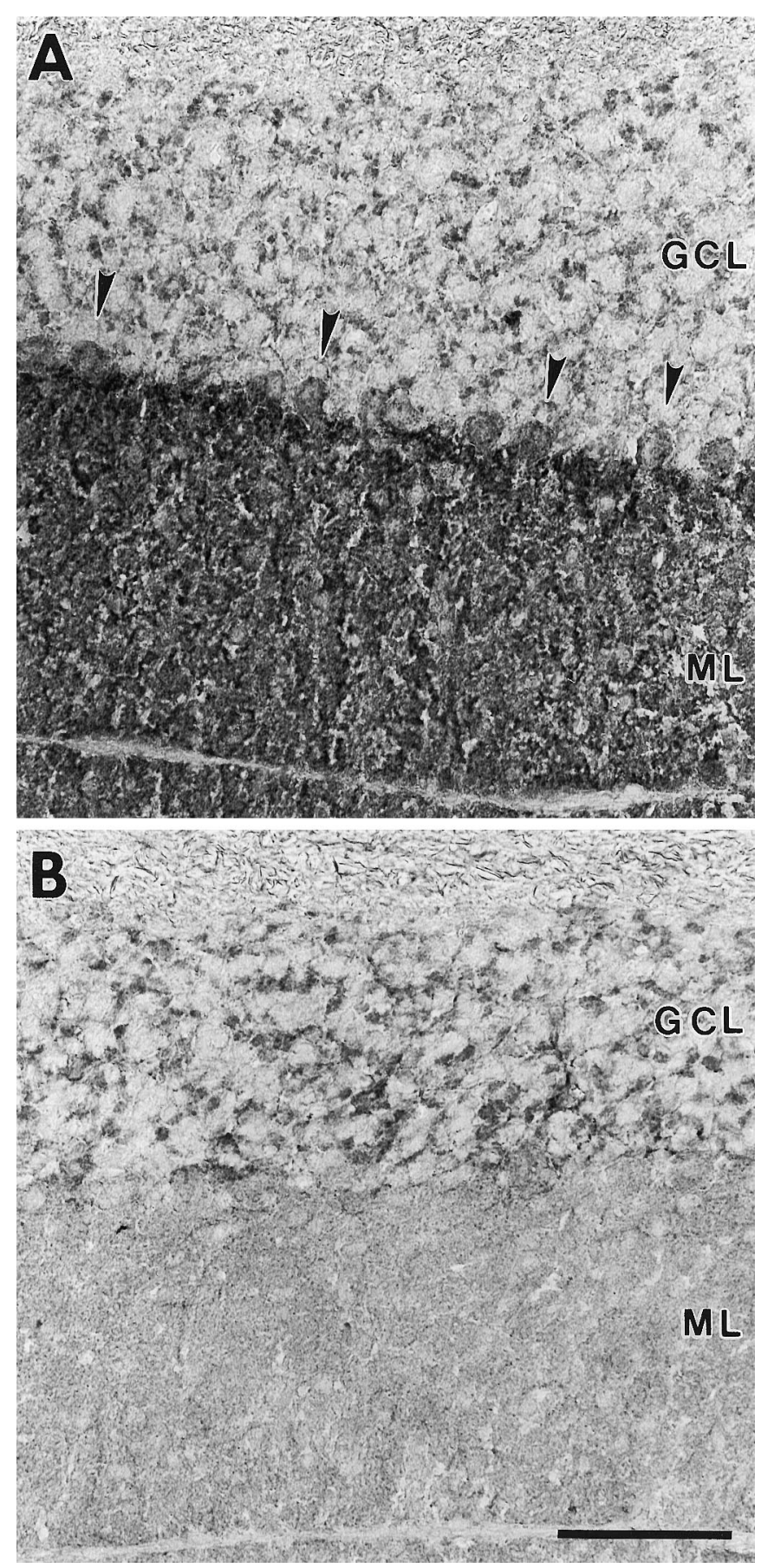

Figure 2. Control stainings of cryostat sections of rat cerebellum with the antiserum directed against mGluR $1 \alpha$ and mGluR5a. $A$, Strong labeling for mGluR $1 \alpha$ was found in the molecular layer $(M L)$ and the Purkinje cell layer (arrowheads point to individual Purkinje cell somata). Weak mGluR1 $\alpha$ immunolabeling was found in the granular cell layer $(G C L)$. $B$, MGluR5a immunolabeling was weak in all three layers, the molecular layer $(M L)$, the Purkinje cell layer, and the granule cell layer $(G C L)$. Scale bar, $100 \mu \mathrm{m}$.

$\mathrm{H}_{2} \mathrm{O}_{2}$. The staining patterns obtained in rat brain (Fig. 2) were compared with published data of the distribution of mGluR1 $\alpha$ and mGluR5a to ensure the specificity to the antibody reactivity. As has been shown for mGluR1 $\alpha$ (Baude et al., 1993) and mGluR5 (Romano et al., 1995), mGluR1 $\alpha$ immunoreactivity in the cerebellum was strong in the molecular layer and the Purkinje cell layer and weak in the granule cell layer (Fig. $2 A$ ), whereas mGluR5a immunoreactivity was weak in the molec- ular layer and Purkinje cell layer and stronger in the granule cell layer (Fig. 2B).

\section{RESULTS}

\section{Distribution of mGluR5a in the adult rat retina}

In the adult retina, mGluR5a immunoreactivity showed a distinct labeling pattern in the IPL, the OPL, and in the inner nuclear layer (INL) (Fig. 3A). Patches of punctate immunoreactivity were seen throughout the IPL with reduced staining in the outer half of the IPL (OFF sublamina) and intense staining in the inner half of the IPL (ON sublamina). A narrow immunoreactive band of processes in the outermost part of the IPL was labeled more strongly. Intense immunoreactivity also was detected in the OPL in putative dendrites of bipolar cells (Fig. $3 A$ ). In the INL, somata and occasionally axons of putative bipolar cells were diffusely labeled (Fig. 3A). Punctate distribution of the mGluR5a receptor staining at the light microscopic level indicated synaptic localization, as was shown for several other types of neurotransmitter receptors in the retina (Pourcho and Owczarzak, 1991; Yazulla and Studholme, 1991; Grünert and Wässle, 1993; Hartveit et al., 1994; Brandstätter et al., 1996). The diffuse labeling on putative bipolar cell somata in the INL, however, also showed extrasynaptic localization of mGluR5a immunolabel. In control experiments, preadsorption of the anti-mGluR5a antiserum with the respective antigenic peptide before applying to retina sections resulted in complete absence of specific staining (Fig. 3B).

To determine whether bipolar cell somata in the INL and their dendrites in the OPL are immunolabeled for mGluR5a, we performed double-labeling experiments with the antiserum against mGluR5a and an antibody against an isoform of protein kinase $\mathrm{C}$ (PKC), shown to stain rod bipolar cells in the rat retina (Greferath et al., 1990) (Fig. 4). These experiments clearly demonstrated that at least rod bipolar cell somata in the INL and their dendrites in the OPL were immunolabeled for mGluR5a (Fig. 4). In the IPL there was no detectable colocalization between the mGluR5a staining and the labeling of rod bipolar cell terminals by the anti-PKC antibody (Fig. 4). The micrographs in Figure 4 were printed as mirror images, and the symmetry of staining that can be detected along the midline (arrows in Fig. 4) shows colocalization.

\section{Subcellular distribution of mGluR5a}

Immunoreactivity for mGluR5a was found intracellularly because of the epitope specificity of the anti-mGluR5a antiserum.

\section{MGluR5a is localized to bipolar cell dendrites in the OPL}

In the OPL, dendrites of bipolar cells postsynaptic to photoreceptor terminals were mGluR5a-immunoreactive (Fig. 5). In the majority of cases the immunolabeled bipolar cell dendrites were detected postsynaptic to the terminals of rod photoreceptors (rod spherules), therefore belonging to rod bipolar cells (Dowling and Boycott, 1966) (Fig. 5A,B). This corroborates the light microscopic finding of mGluR5a-immunoreactive rod bipolar cell somata and dendrites. Horizontal cells, the two lateral postsynaptic elements at the rod photoreceptor synapse in the OPL (Dowling and Boycott, 1966), were never found to be mGluR5aimmunoreactive (Fig. 5A,B). Occasionally, we also found the dendrite of a cone bipolar cell stained for mGluR5a that made contact at the terminal of a cone photoreceptor (cone pedicle) but was not associated directly with the synaptic complex (Fig. 5C).

MGluR5a is localized to amacrine cell processes in the IPL

In the IPL, mGluR5a immunoreactivity was found on amacrine cell processes postsynaptic to bipolar cell ribbon synapses, consis- 

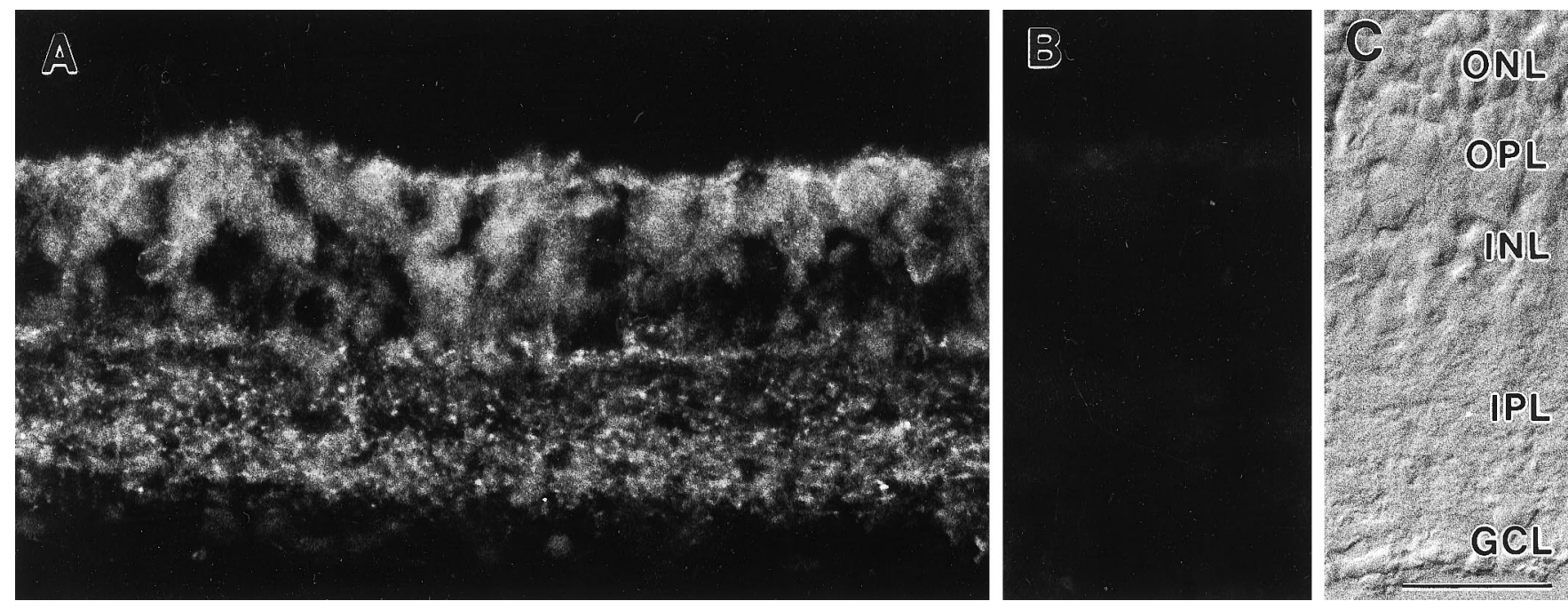

Figure 3. MGluR5a immunostaining of a vertical cryostat section through the rat retina. $A$, Labeling for mGluR5a was present in both synaptic layers, the $O P L$ and the $I P L$, and in the $I N L$. Throughout the $I P L$ diffuse and punctate labeling was present, with stronger staining in the inner half of the $I P L$. In addition, bipolar cell somata in the $I N L$ and their dendrites in the $O P L$ were mGluR5a-immunoreactive. $B$, Preadsorption of anti-mGluR5a antiserum with the immunogen resulted in a complete loss of specific immunoreactivity. $C$, The retinal layers are shown with Nomarski optics. Abbreviations are as in Figure 1. Scale bar, $25 \mu \mathrm{m}$ (shown in $C$ for $A-C$ ).

tent with the light microscopic finding of punctate receptor staining in the IPL (Fig. 3). We detected mGluR5a immunoreactivity on amacrine cell processes postsynaptic to OFF-cone bipolar cell terminals (Fig. 5D), ON-cone bipolar cell terminals (Fig. $5 E$ ), and rod bipolar cell terminals (Fig. $5 F$ ). Whereas at the cone bipolar cell synapses the two postsynaptic elements are preferentially a process of an amacrine cell and a dendrite of a ganglion cell (Dowling and Boycott, 1966), at the rod bipolar cell synapse both postsynaptic elements belong to amacrine cells (Famiglietti and Kolb, 1975; Chun et al., 1993). At the bipolar cell synapses only one of the postsynaptic processes was labeled.

\section{Distribution of mGluR1 $\alpha$ in the adult rat retina}

MGluR1 $\alpha$, the second member of group I mGluRs, like mGluR5a was expressed in both synaptic layers, the OPL and the IPL, of the adult rat retina (Fig. $6 A$ ). In the IPL, staining for mGluR $1 \alpha$ revealed several distinct immunoreactive bands with a mixture of diffuse and punctate staining separated by bands of reduced or no immunoreactivity (Fig. 6A). Whereas the outer half of the IPL (OFF sublamina) was subdivided into three smaller mGluR1 $\alpha$ immunoreactive bands, the complete inner half of the IPL (ON sublamina) showed a more or less homogenous distribution of mGluR $1 \alpha$ immunoreactivity (Fig. $6 A$ ). Clear labeling of a narrow band of mGluR $1 \alpha$-immunoreactive processes also was found in the OPL. In the INL, occasionally labeled somata of putative bipolar cells were detected (Fig. 6A).

\section{Subcellular distribution of mGluR1a}

As with mGluR5a, the reaction product of the mGluR $1 \alpha$ immunostaining was found intracellularly because of the epitope specificity of the antiserum.

\section{$M G l u R 1 \alpha$ is localized to processes postsynaptic to ribbon synapses in the OPL and IPL}

Like the labeling for mGluR5a, mGluR $1 \alpha$ immunoreactivity in the OPL was found in rod bipolar cell dendrites postsynaptic at ribbon synapses of rod photoreceptor cells (Fig. 7A). Only rarely did we find a cone bipolar cell dendrite, postsynaptic to the terminal of a cone photoreceptor cell, stained for mGluR1 $\alpha$ (data not shown). Again, the two lateral horizontal cell processes at the photoreceptor synapse were never found to be mGluR $1 \alpha$ immunoreactive (Fig. 7A).

In the IPL amacrine cell processes postsynaptic to OFF-cone bipolar cell terminals (Fig. $7 B$ ), ON-cone bipolar cell terminals (Fig. $7 C$ ) and rod bipolar cell terminals (Fig. 7D) were labeled for mGluR $1 \alpha$. Like mGluR5a immunoreactivity, mGluR1 $\alpha$ staining was present in only one of the two postsynaptic amacrine cell processes at the rod bipolar cell ribbon synapse. From our material we are not able to say whether ganglion cell dendrites also were stained for mGluR $1 \alpha$.

\section{Postnatal development of mGluR5a and mGluR1 $\alpha$ expression}

During postnatal development, mGluR5a-immunoreactive processes of neurons stratifying in the IPL were detected first at approximately postnatal day $3(\mathrm{P} 3)$ (Fig. $8 B$ ). At around P5 the homogenous mGluR5a labeling pattern in the IPL changed to a more stratified appearance, with stronger staining in the inner part and weaker staining in the outer part of the IPL (Fig. 8C). In addition, the mGluR5a staining was no longer restricted to the IPL but appeared in the somata of putative bipolar cells in the INL and their dendrites in the OPL (Fig. 8C). The adult labeling pattern showing a pronounced stratification of mGluR5a immunostaining in the IPL and clear labeling of bipolar cell somata in the INL and of their dendrites in the OPL was observed already at approximately P8 (Fig. 8D).

In contrast to mGluR5a, low mGluR $1 \alpha$ immunoreactivity was present already at birth (P1) (Fig. 9A). The intensity of mGluR $1 \alpha$ immunoreactivity and the level of stratification of the staining in the IPL increased during the first and second postnatal week, P7-P12 (Fig. 9B,C), and reached the adult staining pattern at approximately P19 (Fig. 9D). Like mGluR5a, the antiserum against mGluR $1 \alpha$ also stained bipolar cell somata in the INL and their dendrites in the OPL, but to a lesser extent (Fig. 9B,C). During later postnatal development, P12-P19, this staining increasingly became restricted to the dendrites of bipolar cells in the OPL (Fig. 9D). 

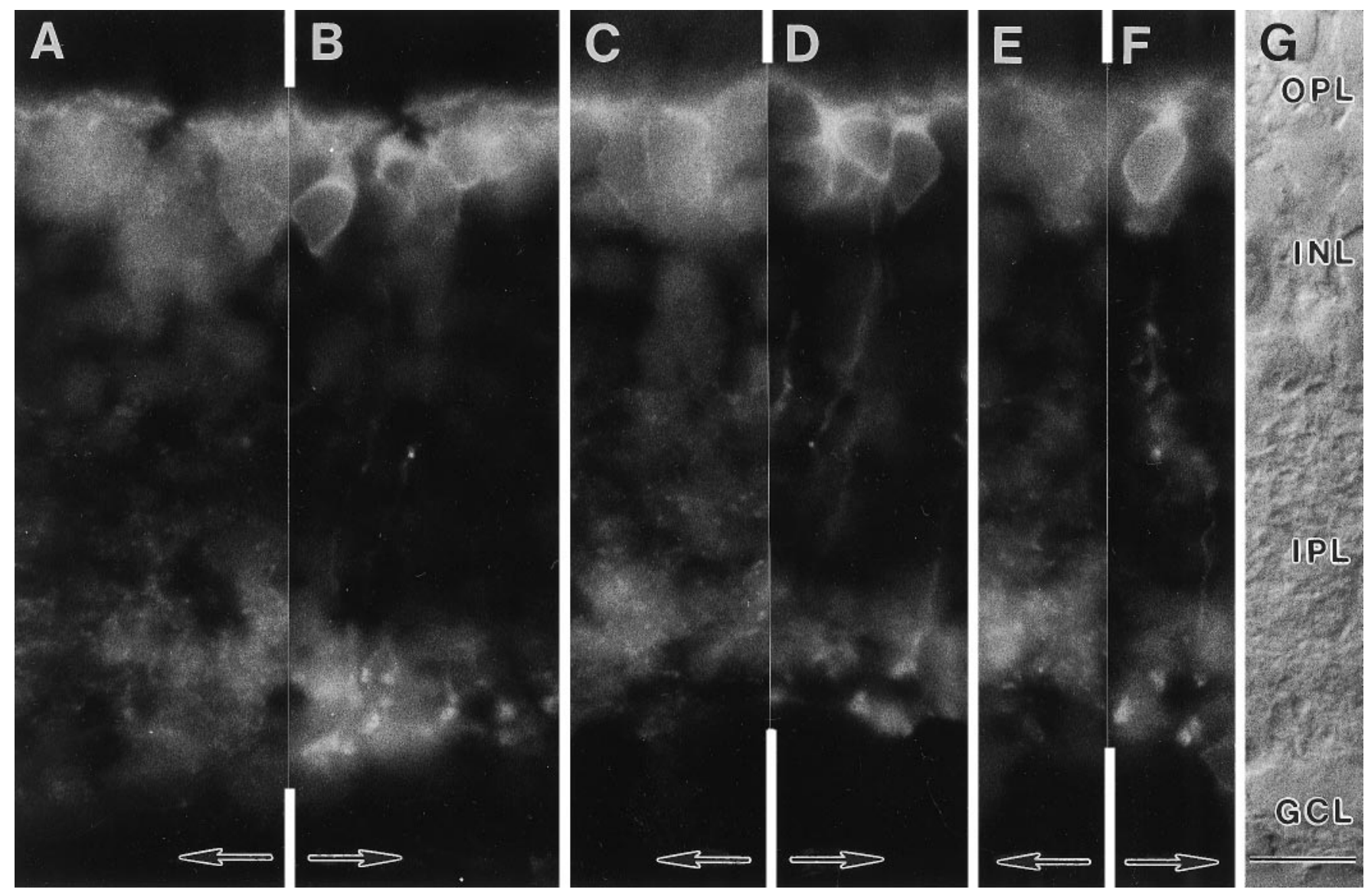

Figure 4. Vertical cryostat sections of rat retina double-labeled with the antiserum against mGluR5a and an antibody against PKC $\alpha$. The micrographs are printed as mirror images and cut and aligned along a common border. Identical points of the sections, therefore, are found at the same distances from the midline (large arrows). $B, D, F$, Rod bipolar cells are stained with an anti-PKC $\alpha$ monoclonal antibody. In the $I N L$ and in the $O P L$ the somata and dendrites of the rod bipolar cells are colocalized with the mGluR5a staining in $A, C$, and $E$, as shown by the symmetry across the midline. In the IPL the mGluR5a staining shows partial colocalization with the terminals of rod bipolar cells. $G$, The retinal layers are shown with Nomarski optics. Abbreviations are as in Figure 1. Scale bar, $10 \mu \mathrm{m}$ (shown in $G$ for $A-G$ ).

\section{DISCUSSION}

\section{MGluR1 $\alpha$ and mGluR5a are involved in synaptic processing in both synaptic layers in the rat retina}

In contrast to the restricted localization of group II and group III mGluRs to either the IPL or the OPL in the rat retina (Nomura et al., 1994; Brandstätter et al., 1996; Koulen et al., 1996), group I mGluRs are present in both synaptic layers. The localization of mGluR $1 \alpha$ and mGluR5a in the IPL and OPL of the rat retina coincides with the distribution of presumed components of second messenger systems involved in group I mGluR signaling. $\mathrm{IP}_{3}$ receptors were found on synaptic processes of amacrine cells as well as in the distal parts of bipolar cell somata (Peng et al., 1991). Other elements of group I mGluR second messenger systems such as $\mathrm{IP}_{3}$ and its precursors also were localized in the retina (Anderson et al., 1985; Das et al., 1986; Milani et al., 1990). Group I mGluRs are activated most strongly by L-quisqualate, and their activation leads to an increase in $\mathrm{IP}_{3}$ synthesis and mobilization of intracellular $\mathrm{Ca}^{2+}$ (for review, see Pin and Duvoisin, 1995). Osborne (1990) found a receptor in the rabbit retina that was activated by quisqualate and stimulated the accumulation of inositol phosphates. Other excitatory amino acid agonists that influence inositol phospholipid metabolism had no effect, and
Osborne (1990) suggested a specific quisqualate receptor in the retina.

The postsynaptic localization of mGluR1 $\alpha$ and mGluR5a on dendrites of bipolar cells in the OPL and on the postsynaptic partners of bipolar cells in the IPL suggests that group I mGluRs take part in synaptic processing in both synaptic layers and are involved in the modulation of synaptic signals in both the photopic and scotopic pathways in the rat retina.

Although activation of mGluR $1 \alpha$ and mGluR5a leads to the same effects in neurons, both receptors were present in dendrites of bipolar cells in the OPL and processes of amacrine cells in the IPL. Examination of the different expression patterns of these two mGluRs in the IPL suggests that different types of amacrine cells express the two mGluRs. However, the bipolar cell dendrites in the OPL seem to label for both mGluRs. Thus, the question arises why a cell would express receptors with the same pharmacological profile at the same site. Only recently it has been shown by Kawabata and colleagues (1996) that, in cells transfected with $\mathrm{mGluR} 1 \alpha$, glutamate caused a single-peaked mobilization of intracellular $\mathrm{Ca}^{2+}$, whereas in mGluR5a-transfected cells, glutamate elicited $\mathrm{Ca}^{2+}$ oscillations caused by differences in phosphorylation sites of the two receptors. These differences could have an impact on intracellular signaling mechanisms in glutamate transmission. 

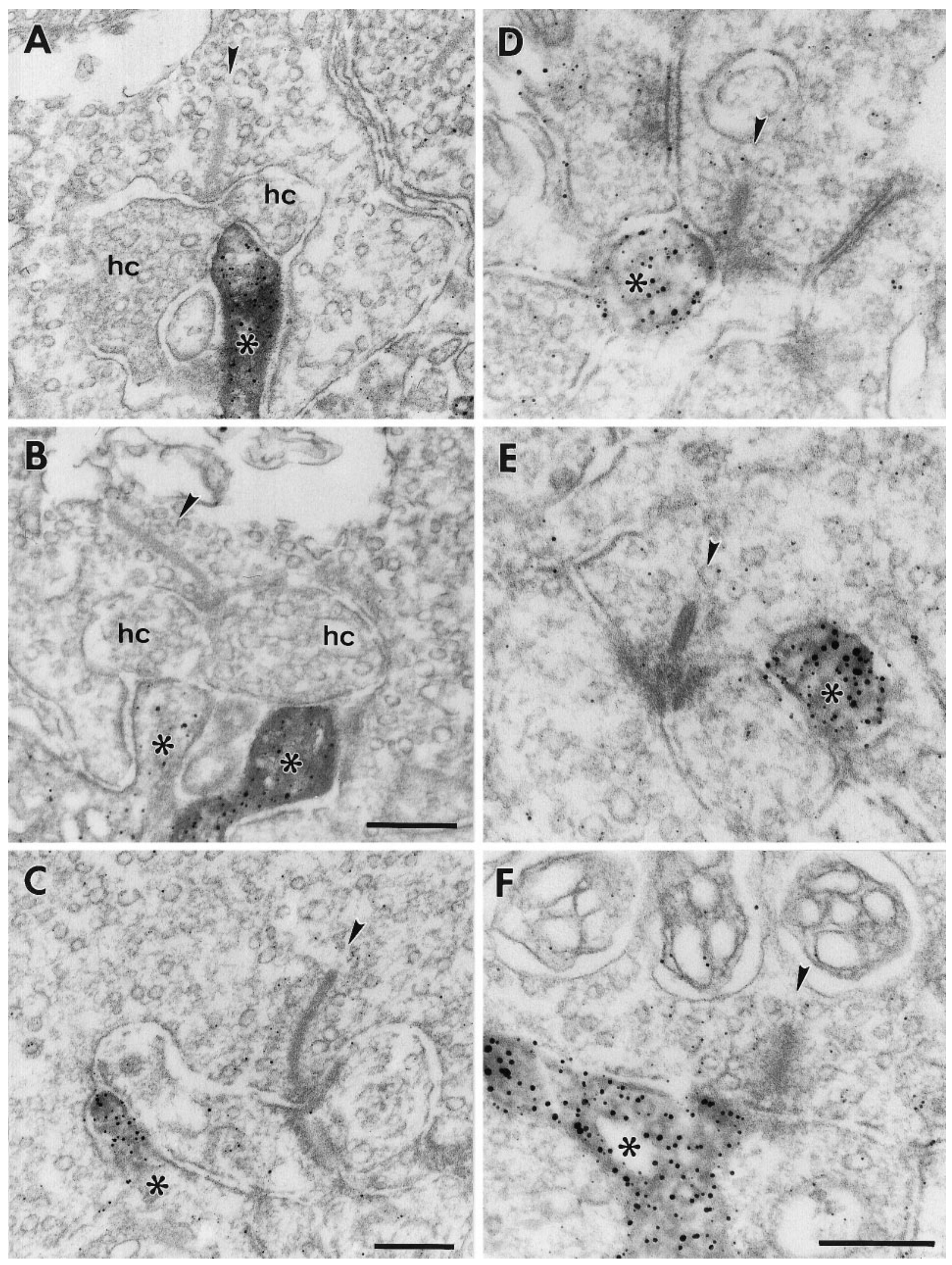

Figure 5. High-power electron micrographs showing the ultrastructural localization of mGluR5a immunoreactivity in the two synaptic layers, the $O P L$ and the $I P L$, in the retina. $A-C$, MGluR5a staining in the $O P L$ was found in the dendrites of rod bipolar cells (star) postsynaptic to rod spherules $(A$, $B$ ) and occasionally in dendrites of cone bipolar cells (star) postsynaptic to cone pedicles $(C)$. The two lateral elements at the photoreceptor synapses, the horizontal cells $(h c)$, were not found to be mGluR5a-immunoreactive. $D-F$, MGluR5a staining in the IPL was found in the processes of amacrine cells (star) postsynaptic to OFF-cone $(D)$, ON-cone $(E)$, and rod bipolar cells $(F)$. The presynaptic ribbon in the terminals of the photoreceptor and bipolar cells is marked with an arrowhead. Scale bars, $0.2 \mu \mathrm{m}$ (shown in $B$ for $A, B$; shown in $F$ for $D-F$ ). 

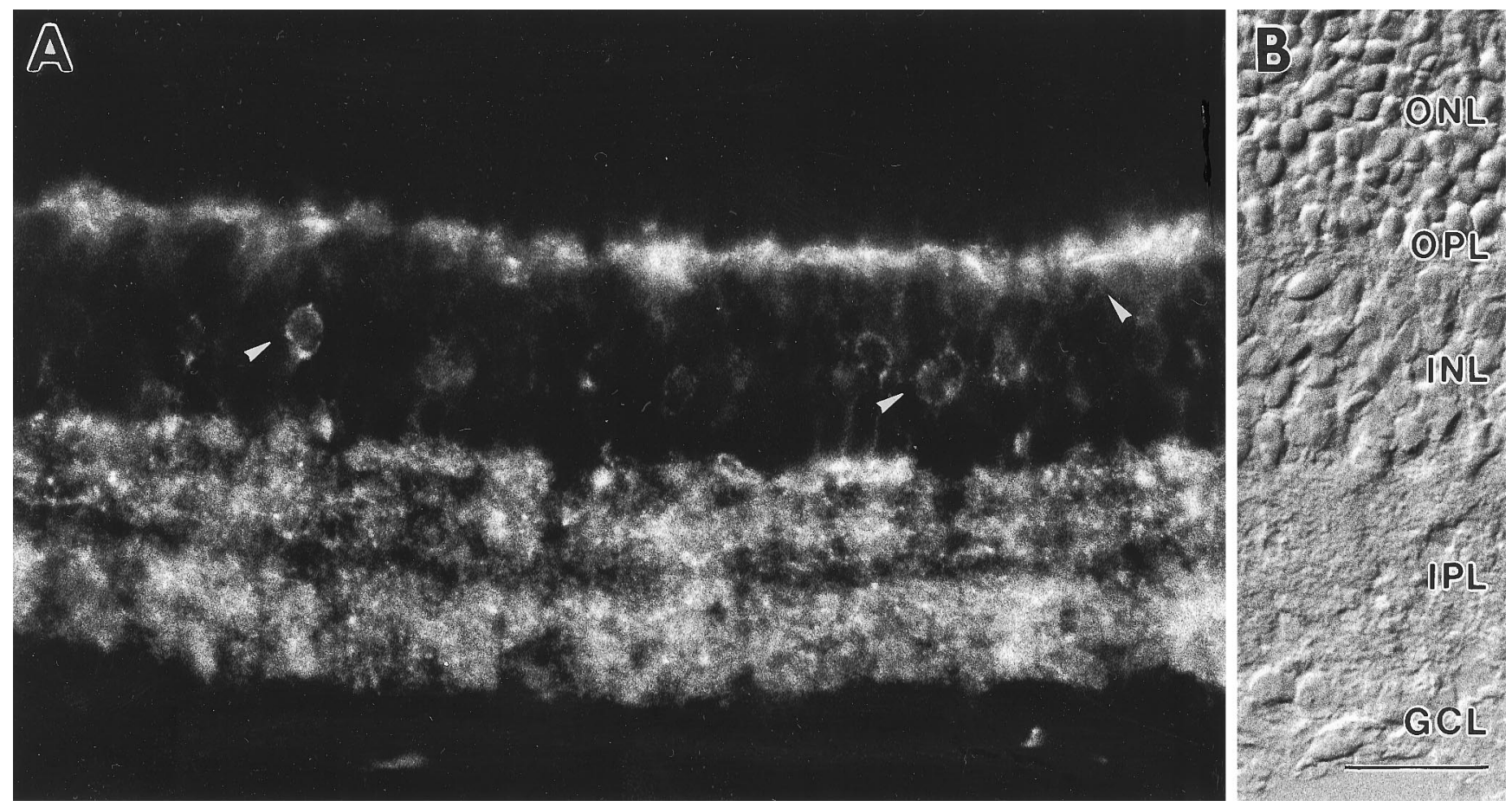

Figure 6. MGluR1 $\alpha$ immunostaining of a vertical cryostat section through the rat retina. $A$, Labeling for mGluR1 $\alpha$ was found in both synaptic layers, the $O P L$ and the IPL. Throughout the IPL diffuse and punctate labeling was present with bands of reduced mGluR1 $\alpha$ immunoreactivity subdividing the $I P L$ into several strata. In addition, somata of bipolar cells (arrowheads) were weakly stained in the INL, as compared with the stronger staining of bipolar cell dendrites in the $O P L$. $B$, The retinal layers are shown with Nomarski optics. Abbreviations are as in Figure 1. Scale bar, $25 \mu \mathrm{m}$ (shown in $B$ for $A, B$ ).

\section{Involvement of group I mGluRs in synaptic processing in the OPL}

MGluR1 $\alpha$ and mGluR5a were found in the OPL of the rat retina preferentially localized to the dendritic tips of rod bipolar cells postsynaptic to the terminals of rod photoreceptor cells. Only on rare occasions staining was found in dendrites of cone bipolar cells postsynaptic to the terminals of cone photoreceptor cells. Rod bipolar cells are ON bipolar cells that are active under scotopic conditions. One of their functions is the transmission of the light $\mathrm{ON}$ signal from the rod photoreceptor cells to the $\mathrm{ON}$ ganglion cells via the AII amacrine cells.

To date, mGluR6 is the sole mGluR found on the dendrites of ON bipolar cells in the OPL (Nomura et al., 1994). The function of mGluR6, sensitive to L-2-amino-4-phosphonobutyrate (L-AP4), is the transmission of the light signal from the photoreceptor cells to the ON bipolar cells; the photoreceptors are hyperpolarized by light, and this hyperpolarization is converted via the action of mGluR6 to a depolarization of the ON bipolar cells that convey the light ON signal to the ON ganglion cells [Masu et al. (1995); for review, see Nakanishi (1995)].

Because of the physiology of group I mGluRs, it is unlikely that they are involved in the direct transmission of synaptic signals in the OPL. Our immunocytochemical data showing group I mGluRs postsynaptic in the dendrites of bipolar cells in the OPL could explain, however, the modulatory action of mGluR agonists on the GABA responses of bipolar cells reported by Feigenspan and Bormann (1994). They showed that extracellular application of 1-amino-cyclopentane-1,3-dicarboxylate (ACPD), an agonist for group I mGluRs (for review, see Pin and Duvoisin, 1995), to retinal bipolar cells in culture stimulated the decline of $\mathrm{GABA}_{\mathrm{C}}$ responses. They suggested that glutamate released from photore- ceptor cells in the OPL could act on mGluRs in bipolar cells, which in turn could decrease the response to inhibitory GABAergic inputs from horizontal or amacrine cells. Stimulation of phospholipase $\mathrm{C}$, increased accumulation of $\mathrm{IP}_{3}$ and diacyl glycerol (DAG), and activation of PKC could lead to phosphorylation of the $\mathrm{GABA}_{\mathrm{C}}$ receptor channels. Group I mGluRs in dendrites of bipolar cells (present study), PKC in dendrites of bipolar cells (Greferath et al., 1990), and $\mathrm{IP}_{3}$ and $\mathrm{GABA}_{\mathrm{C}}$ receptors also found in the OPL in the rat retina (Peng et al., 1991; Enz et al., 1996) could be the anatomical substrates for such an action. For Purkinje cells it has been shown that the action of $\mathrm{IP}_{3}$ on the release of $\mathrm{Ca}^{2+}$ from intracellular stores remains restricted locally to a few micrometers within their dendrites and also is highly regulated temporally (Wang and Augustine, 1995).

\section{Involvement of group I mGluRs in synaptic processing in the IPL}

Both mGluR $1 \alpha$ and mGluR5a were found in amacrine cell processes postsynaptic to bipolar cell ribbon synapses in the IPL. Amacrine cells do not express $\mathrm{GABA}_{\mathrm{C}}$ receptors in the rat retina (Enz et al., 1995), and therefore it is very unlikely that group I mGluRs in the IPL should have the same mode of action as that suggested for mGluR $1 \alpha$ and mGluR5a in bipolar cell dendrites in the OPL. Most amacrine cells are inhibitory interneurons releasing either GABA or glycine (for review, see Wässle and Boycott, 1991). For group II and group III mGluRs present in amacrine cell processes in the IPL, it was suggested that they could influence the release of inhibitory neurotransmitter at reciprocal synapses back onto bipolar cells. Such a mechanism could modulate the release of glutamate from bipolar cells (Brandstätter et al., 1996; Koulen et al., 1996) 

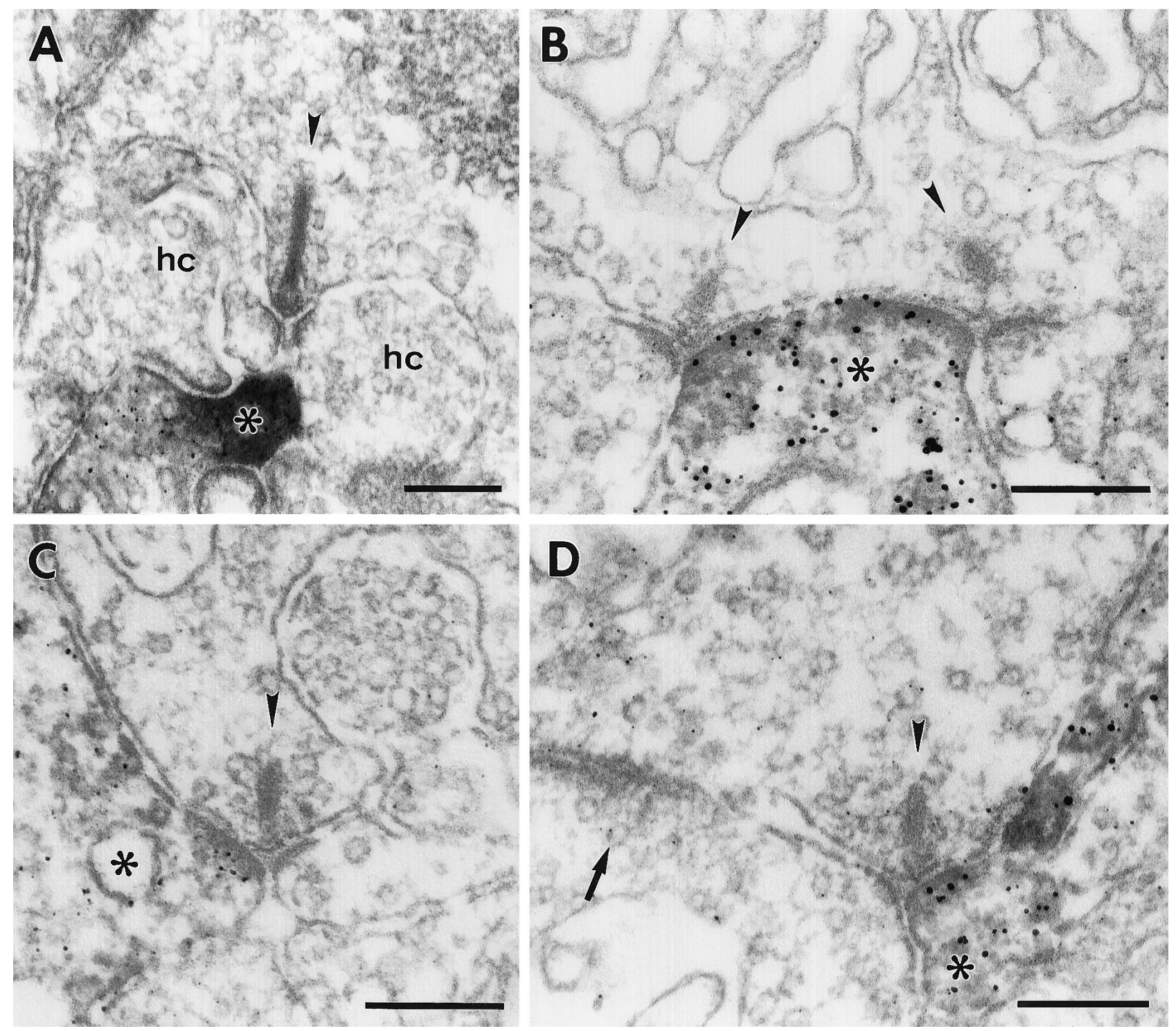

Figure 7. High-power electron micrographs showing the ultrastructural localization of mGluR1 $\alpha$ immunoreactivity in the two synaptic layers. $A$, MGluR1 $\alpha$ staining in the OPL was found in the dendrites of rod bipolar cells (star) postsynaptic to rod spherules. The two lateral elements at the photoreceptor synapses, the horizontal cells $(h c)$, were not found to be mGluR $1 \alpha$-immunoreactive. $B-D$, MGluR1 $\alpha$ staining in the IPL was found in the processes of amacrine cells (star) postsynaptic to OFF-cone $(B)$, ON-cone $(C)$, and rod bipolar cells $(D)$. The presynaptic ribbon in the terminals of the photoreceptor and bipolar cells is marked with an arrowhead. The arrow in $D$ marks a reciprocal synapse in the unlabeled amacrine cell process. Scale bars, $0.2 \mu \mathrm{m}$.

indirectly. Because of the pharmacology of group I mGluRs, characterized by stimulation of PLC, increase of inositol phosphates, and release of $\mathrm{Ca}^{2+}$ from intracellular stores (for review, see Pin and Duvoisin, 1995), we think that a mechanism like that suggested for the action of group II and group III mGluRs in the IPL does not hold true for group I mGluRs. We suggest that group I mGluRs located in the processes of amacrine cells in the IPL could have a general effect on the activity of the cells, which in turn would influence their release probability for neurotransmitter.

\section{Postnatal retinal development of group I mGluR expression}

During postnatal development the expression patterns of mGluR $1 \alpha$ and mGluR5a differed temporally and spatially. Although mGluR1 $\alpha$ was expressed before mGluR5a, both receptors were first present in the IPL, where the earliest synapses form during retinal development (Horsburgh and Sefton, 1987). Only later in development both mGluRs were expressed in neuronal somata in the INL and their processes in the OPL, where synapse formation occurs later than in the IPL. In contrast to different brain regions, where a downregulation was observed for mGluR5 (Romano et al., 1996), mGluR1 $\alpha$ and mGluR5a were upregulated during postnatal retinal development. It has been shown that intracellular levels of free $\mathrm{Ca}^{2+}$ influence neurite elongation and growth cone movement during development (Cohan et al., 1987) and that group I mGluRs are important for neuronal survival during development (Nicoletti et al., 1996; Pizzi et al., 1996). Because of the early appearance of group I mGluRs before synaptogenesis in the rat retina, they could influence synaptic differentiation during postnatal development and also might play 

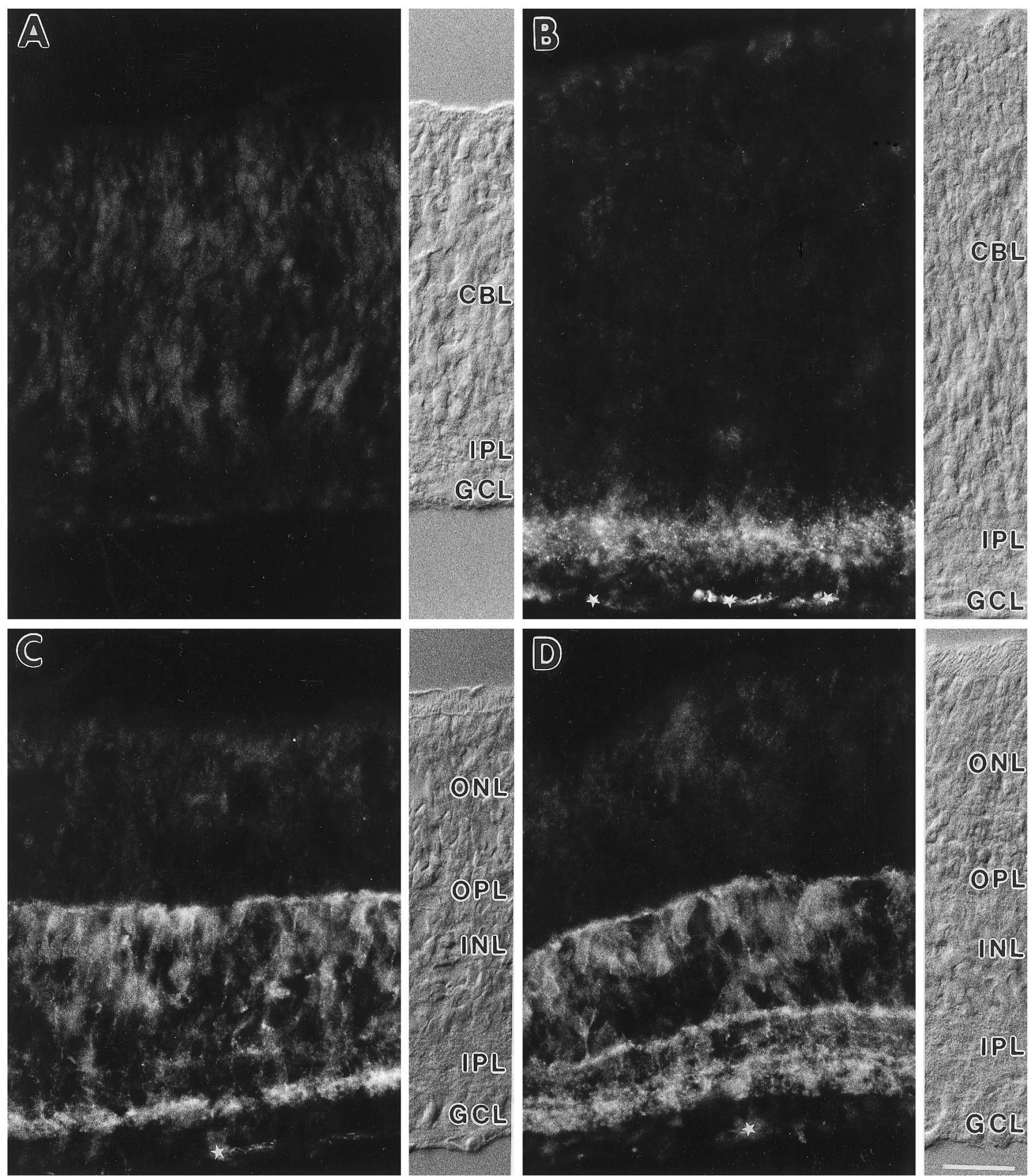

Figure 8. Vertical cryostat sections of rat retinas showing the postnatal development of mGluR5a immunoreactivity. The retinal layers are shown with Nomarski optics accompanying each micrograph (abbreviations as in Fig. 1). $C B L$, Cytoblast layer. $A$, At postnatal day 1 (P1), no mGluR5a-specific staining is found. Only a diffuse background staining in the $C B L$ can be seen. $B$, Diffuse staining of processes in the IPL is seen at P3. $C$, At P5 the staining in the IPL differentiates into strong labeling in the inner half of the IPL and weak staining in the outer half of the IPL. In addition, intense labeling of bipolar cell somata in the $I N L$ and their dendrites in the $O P L$ can be seen. $D$, At approximately P8 the expression of mGluR5a reaches the adult labeling pattern, with distinct stratification of the immunolabeling in the IPL. Stars indicate unspecifically labeled blood vessels. Scale bar (shown in $D$ ), $25 \mu \mathrm{m}$. 

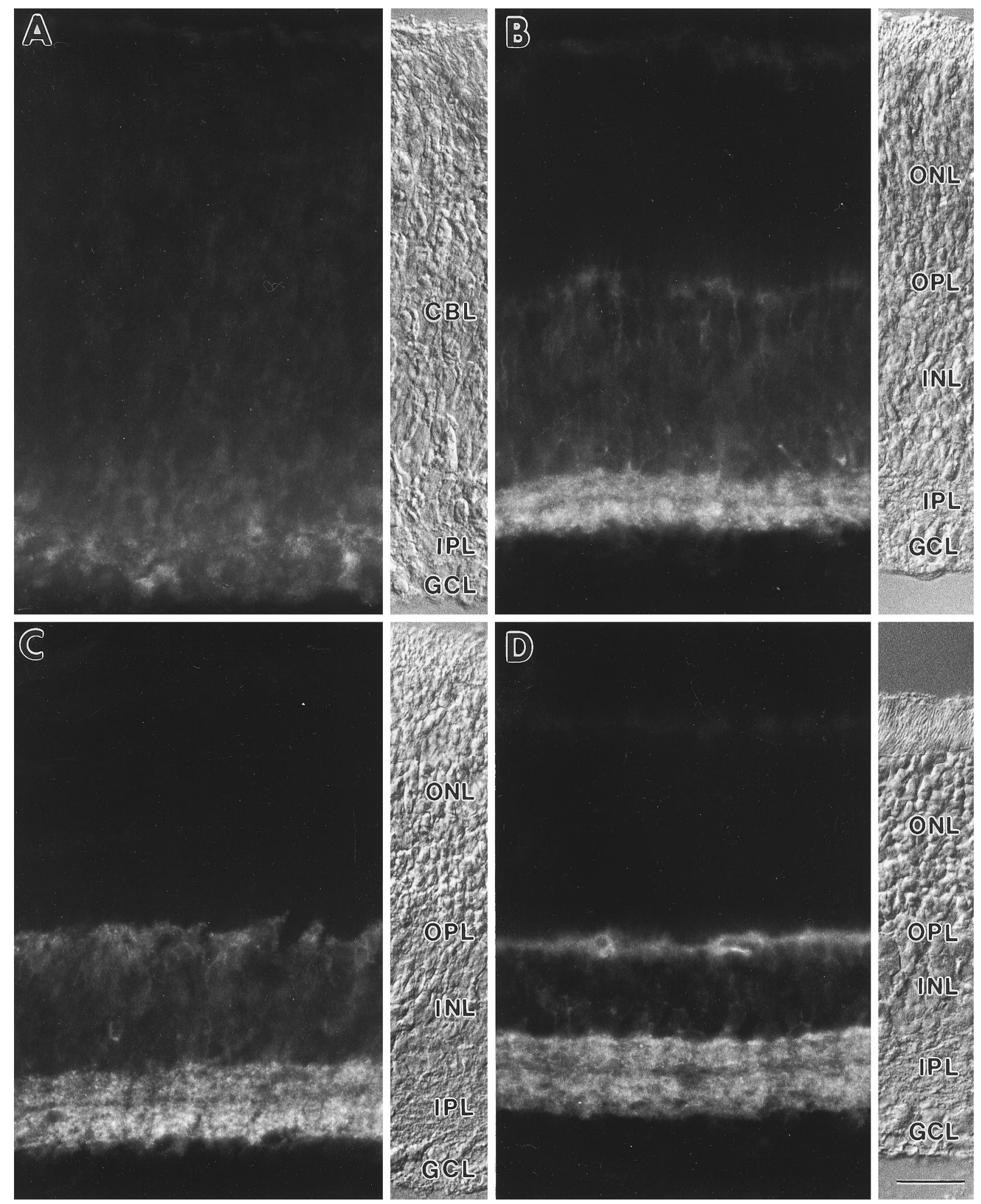

Figure 9. Vertical cryostat sections of rat retinas showing the postnatal development of mGluR1 $\alpha$ immunoreactivity. The retinal layers are shown with Nomarski optics accompanying each micrograph (abbreviations as in Fig. 1). $C B L$, Cytoblast layer. $A$, At postnatal day 1 (P1) weak and diffuse staining for mGluR $1 \alpha$ can be seen in the IPL. B, At approximately P7, the diffuse staining in the IPL becomes more intense, and the staining changes from a homogeneous to a stratified pattern. Faint staining of somata in the $I N L$ and of processes in the $O P L$ also can be seen. $C$, At P12 the staining in the $I P L$ is strong and more punctate, and the labeling in the $I N L$ and $O P L$ shows the somatodendritic staining of bipolar cells. $D$, At approximately P19 the expression of mGluR1 $\alpha$ reaches the adult labeling pattern, with strong labeling in the $I P L$ and weak labeling in the $O P L$. Scale bar (shown in $D$ ), $25 \mu \mathrm{m}$. 
a role in the final consolidation of synaptic connections in the retina (Redburn and Rowe-Rendleman, 1996).

\section{REFERENCES}

Abe T, Sugihara H, Nawa H, Shigemoto R, Mizuno N, Nakanishi S (1992) Molecular characterization of a novel metabotropic glutamate receptor mGluR5 coupled to inositol phosphate $/ \mathrm{Ca}^{2+}$ signal transduction. J Biol Chem 267:13361-13368.

Anderson RE, Maude MB, Pu GA, Hollyfield JG (1985) Effect of light on the metabolism of lipids in the rat retina. J Neurochem 44:773-778.

Aramori I, Nakanishi S (1992) Signal transduction and pharmacological characteristics of a metabotropic glutamate receptor, mGluR1, in transfected CHO cells. Neuron 8:757-765.

Baude A, Nusser Z, Roberts JDB, Mulvihill E, McIlhinney RAJ, Somogyi $\mathrm{P}$ (1993) The metabotropic glutamate receptor (mGluR1 $\alpha$ ) is concentrated at perisynaptic membrane of neuronal subpopulations as detected by immunogold reaction. Neuron 11:771-787.

Brandstätter JH, Koulen P, Kuhn R, van der Putten H, Wässle H (1996) Compartmental localization of a metabotropic glutamate receptor (mGluR7): two different active sites at a retinal synapse. J Neurosci $16: 4749-4756$.

Brecha N (1983) Retinal neurotransmitters: histochemical and biochemical studies. In: Chemical neuroanatomy (Emson PC, ed), pp 85-129. New York: Raven.

Chun M-H, Han S-H, Chung J-W, Wässle H (1993) Electron microscopic analysis of the rod pathway of the rat retina. J Comp Neurol 332:421-432.

Cohan CS, Connor JA, Kater SB (1987) Electrically and chemically mediated increases in intracellular calcium in neuronal growth cones. J Neurosci 7:3588-3599.

Das ND, Yoshioka T, Samuelson D, Shichi H (1986) Immunocytochemical localization of phosphatidylinositol-4,5-bisphosphate in dark- and light-adapted rat retinas. Cell Struct Funct 11:53-63.

Dowling JE, Boycott BB (1966) Organization of the primate retina: electron microscopy. Proc R Soc Lond [Biol] 166:80-111.

Duvoisin RM, Zhang C, Ramonell K (1995) A novel metabotropic glutamate receptor expressed in the retina and olfactory bulb. J Neurosci 15:3075-3083.

Enz R, Brandstätter JH, Hartveit E, Wässle H, Bormann J (1995) Expression of GABA receptor $\rho 1$ and $\rho 2$ subunits in the retina and brain of the rat. Eur J Neurosci 7:1495-1501.

Enz R, Brandstätter JH, Wässle H, Bormann J (1996) Immunocytochemical localization of the $\mathrm{GABA}_{\mathrm{C}}$ receptor $\rho$ subunits in the mammalian retina. J Neurosci 16:4479-4490.

Famiglietti EV, Kolb H (1975) A bistratified amacrine cell and synaptic circuitry in the inner plexiform layer of the retina. Brain Res 84:293-300.

Feigenspan A, Bormann J (1994) Modulation of GABA $_{C}$ receptors in rat retinal bipolar cells by protein kinase C. J Physiol (Lond) 481:325-330

Greferath U, Grünert U, Wässle H (1990) Rod bipolar cells in the mammalian retina show protein kinase C-like immunoreactivity. J Comp Neurol 301:433-442.

Grünert U, Wässle H (1993) Immunocytochemical localization of glycine receptors in the mammalian retina. J Comp Neurol 335:523-537.

Hartveit E, Brandstätter JH, Sassoè-Pognetto M, Laurie DJ, Seeburg PH, Wässle H (1994) Localization and developmental expression of the NMDA receptor subunit NR2A in the mammalian retina. J Comp Neurol 348:570-582.

Hartveit E, Brandstätter JH, Enz R, Wässle H (1995) Expression of the mRNA of seven metabotropic glutamate receptors (mGluR1 to 7) in the rat retina. An in situ hybridization study on tissue sections and isolated cells. Eur J Neurosci 7:1472-1483.

Hollmann M, Heinemann S (1994) Cloned glutamate receptors. Annu Rev Neurosci 17:31-108.

Horsburgh GM, Sefton AJ (1987) Cellular degeneration and synaptogenesis in the developing retina of the rat. J Comp Neurol 263:553-566.

Kawabata S, Tsutsumi R, Kohara A, Yamaguchi T, Nakanishi S, Okada M (1996) Control of calcium oscillations by phosphorylation of metabotropic glutamate receptors. Nature 383:89-92.

Koulen P, Malitschek B, Kuhn R, Wässle H, Brandstätter JH (1996) Group II and group III metabotropic glutamate receptors in the rat retina: distributions and developmental expression patterns. Eur J Neurosci 8:2177-2187.
Marc RE (1989) The role of glycine in the mammalian retina. In: Progress in retinal research (Osborne N, Chader J, eds), pp 67-107. Oxford: Pergamon.

Massey SC (1990) Cell types using glutamate as a neurotransmitter in the vertebrate retina. In: Progress in retinal research (Osborne N, Chader J, eds), pp 399-425. Oxford: Pergamon.

Massey SC, Redburn DA (1987) Transmitter circuits in the vertebrate retina. Prog Neurobiol 28:55-96.

Masu M, Tanabe Y, Tsuchida K, Shigemoto R, Nakanishi S (1991) Sequence and expression of a metabotropic glutamate receptor. Nature 349:760-765.

Masu M, Iwakabe H, Tagawa Y, Miyoshi T, Yamashita M, Fukuda Y, Sasaki H, Hiroi K, Nakamura Y, Shigemoto R, Takada M, Nakamura K, Nakao K, Katsuki M, Nakanishi S (1995) Specific deficit of the ON response in visual transmission by targeted disruption of the mGluR6 gene. Cell 80:757-765.

Milani D, Facci L, Buso M, Toffano G, Leon A, Skaper SD (1990) Excitatory amino acid receptor agonists stimulate membrane inositol phospholipid hydrolysis and increase cytoplasmic free $\mathrm{Ca}^{2+}$ in primary cultures of retinal neurons. Cell Signal 2:359-368.

Monaghan DT, Bridges RJ, Cotman CW (1989) The excitatory amino acid receptors: their classes, pharmacology, and distinct properties in the function of the central nervous system. Annu Rev Pharmacol Toxicol 29:365-402.

Nakajima Y, Iwakabe H, Akazawa C, Nawa H, Shigemoto R, Mizuno N, Nakanishi S (1993) Molecular characterization of a novel retinal metabotropic glutamate receptor mGluR6 with a high agonist selectivity for L-2-amino-4-phosphonobutyrate. J Biol Chem 268:11868-11873.

Nakanishi S (1994) Metabotropic glutamate receptors: synaptic transmission, modulation, and plasticity. Neuron 13:1031-1037.

Nakanishi S (1995) Second-order neurones and receptor mechanisms in visual and olfactory information processing. Trends Neurosci 18:359-364.

Nicoletti F, Bruno V, Copani A, Casabona G, Knöpfel T (1996) Metabotropic glutamate receptors: a new target for the therapy of neurodegenerative disorders? Trends Neurosci 19:267-271.

Nomura A, Shigemoto R, Nakamura Y, Okamoto N, Mizuno N, Nakanishi S (1994) Developmentally regulated postsynaptic localization of a metabotropic glutamate receptor in rat rod bipolar cells. Cell 77:361-369.

Okamoto N, Hori S, Akazawa C, Hayashi Y, Shigemoto R, Mizuno N, Nakanishi S (1994) Molecular characterization of a new metabotropic glutamate receptor mGluR7 coupled to inhibitory cyclic AMP signal transduction. J Biol Chem 269:1231-1236.

Osborne NN (1990) Stimulatory and inhibitory actions of excitatory amino acids on inositol phospholipid metabolism in rabbit retina. Evidence for a specific quisqualate receptor subtype associated with neurones. Exp Eye Res 50:397-405.

Peng Y-W, Sharp AH, Snyder SH, Yau K-W (1991) Localization of inositol 1,4,5-trisphosphate receptor in synaptic terminals in the vertebrate retina. Neuron 6:525-531.

Peng Y-W, Blackstone CD, Huganir RL, Yau KW (1995) Distribution of glutamate receptor subtypes in the vertebrate retina. Neuroscience 66:483-497.

Pin JP, Duvoisin R (1995) Neurotransmitter receptors. I. The metabotropic glutamate receptors: structure and functions. Neuropharmacology 34:1-26.

Pizzi M, Consolandi O, Memo M, Spano P (1996) Activation of multiple metabotropic glutamate receptor subtypes prevents NMDA-induced excitotoxicity in rat hippocampal slices. Eur J Neurosci 8:1516-1521.

Pourcho RG, Owczarzak Z (1991) Glycine receptor immunoreactivity is localized at amacrine synapses in cat retina. Vis Neurosci 7:611-618.

Redburn DA, Rowe-Rendleman C (1996) Developmental neurotransmitters. Signals for shaping neuronal circuitry. Invest Ophthalmol Vis Sci 37:1479-1482.

Romano C, Sesma MA, McDonald CT, O’Malley K, van den Pol AN, Olney JW (1995) Distribution of metabotropic glutamate receptor mGluR5 immunoreactivity in rat brain. J Comp Neurol 355:455-469.

Romano C, van den Pol AN, O'Malley KL (1996) Enhanced early developmental expression of the metabotropic glutamate receptor mGluR5 in rat brain: protein, mRNA slice variants, and regional distribution. J Comp Neurol 367:403-412.

Saugstad JA, Kinzie JM, Mulvihill ER, Segerson TP, Westbrook GL (1994) Cloning and expression of a new member of the L-2-amino-4- 
phosphonobutyric acid-sensitive class of metabotropic glutamate receptors. Mol Pharmacol 45:367-372.

Seeburg PH (1993) The molecular biology of mammalian glutamate receptor channels. Trends Neurosci 16:359-365.

Tanabe Y, Masu M, Ishii T, Shigemoto R, Nakanishi S (1992) A family of metabotropic glutamate receptors. Neuron 8:169-179.

Tanabe Y, Nomura A, Masu M, Shigemoto R, Mizuno N, Nakanishi S (1993) Signal transduction, pharmacological properties, and expression patterns of two rat metabotropic glutamate receptors, mGluR3 and mGluR4. J Neurosci 13:1372-1378.

Vidnyánszky Z, Hámori J, Négyessy L, Rüegg D, Knöpfel T, Kuhn R, Görcs TJ (1994) Cellular and subcellular localization of the mGluR5a metabotropic glutamate receptor in rat spinal cord. NeuroReport 6:209-213.

Wang SS-H, Augustine GJ (1995) Confocal imaging and local photolysis of caged compounds: dual probes of synaptic function. Neuron $15: 755-760$.

Wässle H, Boycott BB (1991) Functional architecture of the mammalian retina. Physiol Rev 71:447-480.

Yazulla S (1986) GABAergic mechanisms in the retina. In: Progress in retinal research (Osborne $\mathrm{N}$, Chader $\mathrm{J}$, eds), pp 1-52. Oxford: Pergamon.

Yazulla S, Studholme KM (1991) Glycine-receptor immunoreactivity in retinal bipolar cells is postsynaptic to glycinergic and GABAergic amacrine cell synapses. J Comp Neurol 310:11-20. 